Jurnal Kependudukan Indonesia | Edisi Khusus Demografi dan COVID-19, Juli 2020 |7-10

JURNAL KEPENDUDUKAN INDONESIA

p-ISSN : 1907-2902 (Print)

e-ISSN : 2502-8537 (Online)

\title{
PERTIMBANGAN DEMOGRAFIS DI TENGAH PANDEMI COVID-19: KEBIJAKAN PEMBATASAN PERJALANAN KE PROVINSI PAPUA
}

\section{(DEMOGRAPHIC CONSIDERATIONS IN THE MIDST OF COVID-19: TRAVEL RESTRICTION POLICY TO PAPUA PROVINCE)}

\author{
Jevon E. M. Nahuway ${ }^{1}$, Johni R.V. Korwa ${ }^{2 *}$ \\ ${ }^{1}$ Mahasiswa Program Studi Hubungan Internasional, Fakultas Ilmu Sosial dan Ilmu Politik, Universitas Cenderawasih \\ ${ }^{2}$ Dosen Program Studi Hubungan Internasional, Fakultas Ilmu Sosial dan Ilmu Politik, \\ Universitas Cenderawasih, \\ *Korespondesi penulis: johnikorwa@gmail.com
}

\begin{abstract}
This paper aims to analyze travel restriction policy to Papua in the midst of the COVID-19 pandemic through a demographic lens. It finds that the travel restriction policy to Papua was not only influenced by non-demographic factors including politics, economy, health, but also by demographic factors such as mortality, fertility, and migration. There are several reasons for this. Firstly, the population of Papua remained small in comparison with other provinces across Indonesia; thereby imposing travel restrictions were in the best interest to lower the mortality rate in Papua due to COVID-19. Secondly, preserving fertility during the COVID-19 pandemic was vitally important regarding future generations and the government of Papua had demonstrated its ability to handle the situation by appointing several health centers particularly for pregnant women. Thirdly, people moving in and out of Papua currently became inevitable, thus migration should be limited for a while through the travel restriction policy.
\end{abstract}

Keywords: COVID-19, Indonesia, Papua, travel restriction

Papua merupakan Provinsi terbesar di Indonesia dengan luas wilayah $319.036,05 \mathrm{~km}^{2}$ atau setara $16,64 \%$ dari luas Indonesia. Meskipun demikian, jumlah penduduk Papua masih cukup sedikit jika dibandingkan dengan provinsi lainnya yaitu 3.379,3000 (BPS, 2020). Dalam konteks pencegahan COVID-19, Papua adalah provinsi pertama di Indonesia yang secara tegas menyatakan penutupan sementara akses perjalanan baik melalui laut maupun udara, kecuali untuk kargo barang atau yang bersifat darurat. Hal ini tertuang pada salah satu poin hasil 'Kesepakatan Bersama' antara Gubernur dan Forkopimda (forum koordinasi pimpinan daerah), bupati/walikota beserta seluruh stakeholders di Papua pada tanggal 24 Maret 2020 yang menyatakan, "penutupan sementara seluruh bandar udara, pelabuhan laut, dan pos lintas batas negara di Papua" (Hasil Kesepakatan Bersama, 2020). Walaupun sempat mendapat penolakan dari Menteri Dalam Negeri Tito Karnavian karena dianggap tidak sejalan dengan instruksi pemerintah pusat yang menekankan pada social/physical distancing; bukan penutupan akses travel (Nugraheny, 2020); implementasi kesepakatan tersebut tetap dijalankan.

Dalam perspektif negara kesatuan, pembatasan perjalanan ke Papua belum mendapat legitimasi dari pemerintah pusat. Payung hukum untuk melakukan penutupan akses travel adalah melalui kebijakan Pembatasan Sosial Skala Besar (PSBB) yang ternyata 
dikeluarkan Presiden Jokowi satu minggu setelah pembatasan akses ke Papua diberlakukan, yaitu tanggal 31 Maret 2020. Penetapan PSBB pun harus mendapat persetujuan dari Menteri Kesehatan, dan Papua tercatat belum mendapat status PSBB sampai saat penulisan paper ini. Tentunya ada banyak pertimbangan mengapa para pengambil keputusan di Papua bersikukuh untuk tetap melakukan pembatasan perjalanan ditengah pandemi COVID-19.

Korwa (2020) berpendapat bahwa terdapat ketidakpercayaan (distrust) pada kemampuan otoritas nasional untuk menekan laju penyebaran COVID-19 sehingga mendorong para pengambil keputusan di Papua menutup akses masuk wilayah. Selain itu, minimnya sumber daya (professional) dan infrastruktur kesehatan di Papua juga menjadi pertimbangan krusial terkait pembatasan perjalanan (Mawel \& Mambor, 2020). Dalam konteks ini, penulis berpendapat bahwa pertimbangan demografis juga telah menjadi bagian tak terpisahkan dari pengambilan keputusan untuk pembatasan perjalanan (travel restriction) ke Papua di masa pandemi COVID-19.

Ada tiga variabel demografis yaitu 1) tingkat kematian;

2) tingkat kelahiran; dan 3) migrasi masuk (Hardiani,
2009). Seperti yang dijelaskan sebelumnya, jumlah penduduk di Papua masih cukup sedikit jika di bandingkan dengan luas wilayahnya. Artinya bahwa jika semakin banyak masyarakat Papua yang terinfeksi dan meninggal akibat wabah COVID-19 maka populasi Papua tentunya akan menurun. Namun fakta menunjukkan bahwa angka kematian pasien COVID-19 di Papua sangat kecil sejak pembatasan perjalanan diberlakukan.

Hal ini dapat dilihat pada Gambar 1 yang mendeskripsikan bahwa meskipun jumlah kasus positif dan pasien sembuh meningkat, angka kematian sangat rendah dengan trending stabil selama periode ditunjukkan. Gambar 1 juga didukung oleh pernyataan dr. Silwanus Sumule - Juru Bicara Tim Gugus Tugas Percepatan Penanganan COVID-19 Papua bahwa per 25 Mei angka kematian 11 orang atau hanya 1,7\% (Seputar Papua, 2020). Dengan kata lain, pemerintah Papua telah mampu menekan angka kematian sebagai bagian dari pertimbangan demografis dan tentunya diharapkan agar jumlah pasien positif COVID-19 di Papua dapat menjadi sembuh dalam beberapa waktu ke depan.

Gambar 1. Perbandingan antara pasien meninggal dengan kasus positif dan sembuh COVID-19 di Provinsi Papua (22 Maret - 31 Mei 2020)

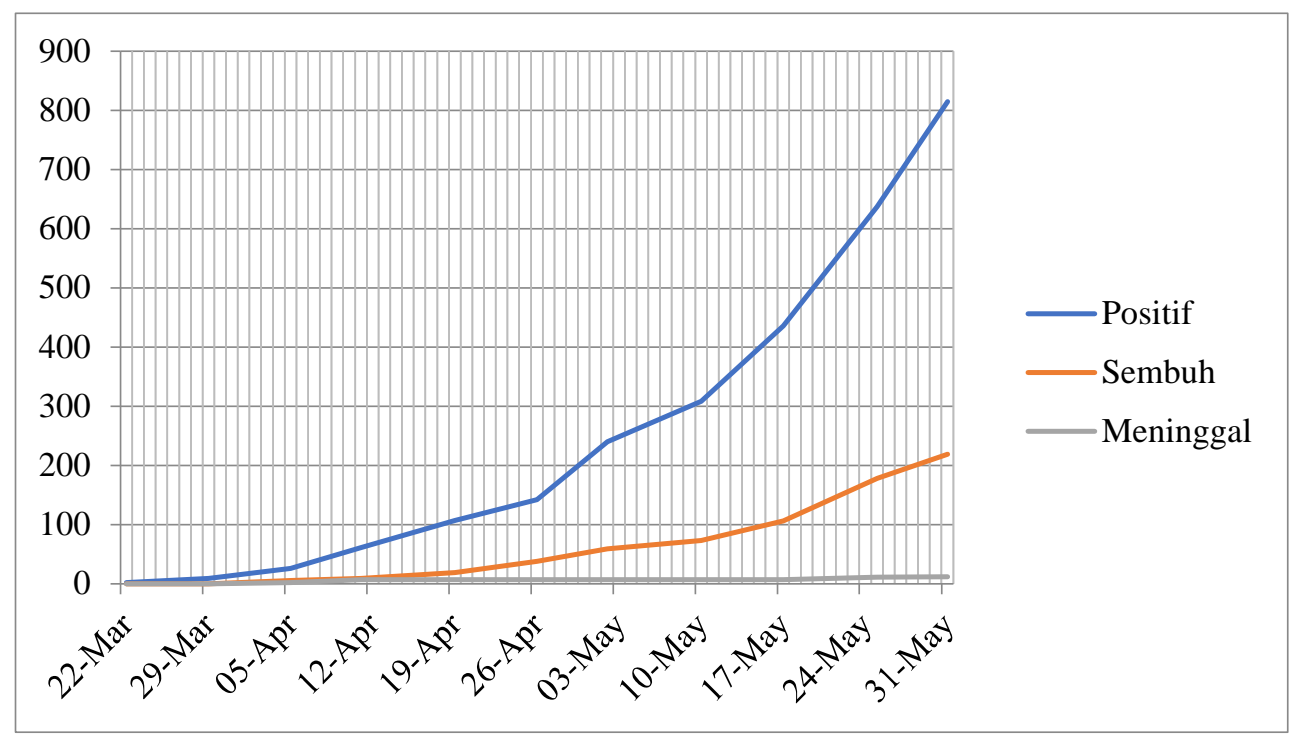

Sumber: Diolah oleh penulis dari 'Satgas Pengendalian Pencegahan Penanganan COVID-19 Provinsi Papua (2020)' 
Tingkat kelahiran juga menjadi pertimbangan tersendiri dalam pembatasan perjalanan ke Papua. Dalam konteks pandemi ini, Pemerintah Provinsi berusaha memproteksi ibu hamil dan anak yang dilahirkan dari infeksi COVID-19. Bayangkan jika banyak ibu hamil di Papua yang terpapar wabah COVID-19? Bagaimana nasib masa depan anak-anak generasi Papua? Tentunya infeksi tersebut akan memberi kontribusi buruk dan tidak menunjang angka kelahiran di Papua serta mempengaruhi kesehatan anak yang dilahirkan. Keseriusan pemerintah dalam mendukung tingkat kelahiran di tengah situasi pandemi saat ini dapat dilihat di ibu kota Provinsi Papua - Kota Jayapura episentrum COVID-19 dengan jumlah kasus tertinggi. Seperti yang dikatakan oleh Kepala Dinas Kota Jayapura, dr. Ni Nyoman Sri Antari bahwa pihaknya telah menyiapkan 13 Puskesmas khusus untuk menerima persalinan partus normal, dan semua petugas medis Puskesmas juga telah dilengkapi dengan APD /Alat Pelindung Diri (Suara Papua, 2020).

Terakhir, pembatasan perjalanan ke Papua tidak terlepas dari pertimbangan arus migrasi dalam beberapa periode terakhir. Papua sejak lama telah menjadi sasaran empuk migrant dan transmigrasi; kemudian terhenti lewat penolakan melalui Peraturan Daerah Provinsi Kependudukan No. 15 Tahun 2008 (Yuminarti, 2017; Pona, 2008). Namun, arus masukkeluar orang ke wilayah Papua baik melalui darat maupun laut masih sangat gencar dengan berbagai pertimbangan. Hal inilah yang mendasari penutupan sementara perjalanan ke Papua sebagai langkah pencegahan COVID-19 dari luar Papua (imported cases).

Seperti yang diketahui bahwa kasus positif di Papua pertama kali ditemukan di Kabupaten Merauke pada 22 Maret yang memiliki riwayat perjalanan dari daerah terpapar COVID-19 (Aditra, 2020). Seiring perkembangan waktu, dua cluster lainnya ditemukan ditengarai beberapa masyarakat itu sebelumnya melakukan perjalanan ke Lembang dan Gowa, dan ketika kembali ke Papua kemudian berinteraksi dengan masyarakat sehingga terjadi penularan lokal (Pemerintah Provinsi Papua, 2020). Fenomena ini kemudian membuktikan bahwa perjalanan masuk/keluar Papua perlu dihentikan sementara waktu guna mencegah resiko orang yang terjangkit COVID-
19 masuk ke Papua melalui proses migrasi dan untuk memetakan persebaran transmisi lokal.

\section{KESIMPULAN}

Tulisan ini menganalisa kebijakan pembatasan perjalanan ke Papua di masa pandemi COVID-19 dalam perspektif demografi. Perspektif ini digunakan untuk melihat sisi lain dalam pengambilan keputusan. Tulisan ini menemukan bahwa kebijakan pembatasan perjalanan ke Papua tidak hanya dipengaruhi oleh faktor-faktor non-demografi seperti politik, ekonomi, kesehatan, tetapi juga oleh unsur-unsur demografis seperti tingkat kematian, tingkat kelahiran, dan migrasi masuk.

Penulis merangkum beberapa poin penting. Pertama, angka kematian yang rendah dan relatif stabil di Papua membuktikan keberhasilan manajemen daerah melalui pembatasan perjalanan dalam mengontrol tingkat kematian akibat COVID-19. Kedua, kesigapan pemerintah dalam memproteksi tingkat kelahiran dimasa pendemi sudah cukup baik melalui penunjukkan beberapa Puskesmas untuk persalinan ibu hamil. Ketiga, penularan COVID-19 di Papua disebabkan oleh warga yang bepergian ke luar daerah dan juga ada resiko dibawa oleh orang luar ketika bermigrasi ke Papua. Oleh karena itu, tindakan pembatasan perjalanan merupakan hal yang tepat. Rekomendasi dari penulis adalah pemerintah Papua harus terus menopang tim medis dalam proses treatment terhadap pasien positif untuk sembuh sehingga angka kematian COVID-19 tetap berada dalam level rendah, dan tetap membatasi perjalanan hingga jumlah kasus mencapai titik puncak dan menurun.

\section{DAFTAR PUSTAKA}

Aditra, I.P. (2020, Maret 3). Satu Pasien Covid-19 di Merauke adalah Tenaga Kesehatan. Kompas. https://regional.kompas.com/read/2020/03/22/205 20011/satu-pasien-positif-covid-19-di-meraukeadalah-tenaga-kesehatan

Badan Pusat Statistik [BPS]. (2020). Statistik Indonesia 2020.

https://www.bps.go.id/publication/2020/04/29/e9 011b3155d45d70823c141f/statistik-indonesia2020.html 
Hasil Kesepakatan Bersama. (2020). Kesepakatan Bersama Pencegahan, Pengendalian, dan Penanggulangan COVID-19 di Provinsi Papua.

Hardiani, J. (2009). Dasar-dasar Teori Kependudukan. Jakarta: Hamada Prima.

Korwa, J. R. V. (2020). Coronavirus ( COVID-19) and Papua1: Putting People First. Department of Pacific Affairs ANU In Brief 2020/15. doi: $10.25911 / 5$ ec659100053b

Mawel, B., \& Mambor, V. (2020, Maret 25). Papua restricts entry as concerns mount over lack of facilities to treat COVID-19. The Jakarta Post. https://www.thejakartapost.com/news/2020/03/2 5/papua-restricts-entry-as-concerns-mount-overlack-of-facilities-to-treat-covid-19.html

Nugraheny, D. E. (2020, Maret 25). Mendagri Tak Setuju Pemprov Papua Tutup Wilayah akibat Covid-19.

Kompas.com. https://nasional.kompas.com/read/2020/03/25/07 591621/mendagri-tak-setuju-pemprov-papuatutup-wilayah-akibat-covid-19

Pemerintah Provinsi Papua. (2020). Positif COVID-19 Papua Kini Sudah 95 Kasus. https://www.papua.go.id/view-detail-berita- 7213/positif-covid-19-papua-kini-sudah-95kasus.html

Pona, L. (2008). Penduduk, otonomi khusus, dan fenomena konflik di Tanah Papua. Jurnal Kependudukan Indonesia, 3(1), 51-67. https://doi.org/10.14203/jki.v3i1.163

Seputar Papua. (2020). Mimika Urutan Pertama Jumlah Pasien Corona Sembuh Tertinggi di Papua. https://seputarpapua.com/view/mimika-urutanpertama-jumlah-pasien-corona-sembuh-tertinggidi-papua.html\#

Suara Papua. (2020). 8 Rumah Sakit Fokus Corona, Ibu Hamil Siap bersalin di Puskesmas. https://suarapapua.com/2020/05/07/8-rumahsakit-fokus-corona-ibu-hamil-siap-bersalin-dipuskesmas/

Yuminarti, U. (2017). Kebijakan Transmigrasi dalam Kerangka Otonomi Khusus di Papua: Masalah dan Harapan ( Transmigration Policy in the Context of Special Autonomy in Papua: Problems and Expectations ). Jurnal Kependudukan Indonesia, 12(1), $13-24$ https://doi.org/10.14203/jki.v12i1.215 